УДК 504.61:621.311.22

(C) 3.С. Сірко, к.т.н.

Національний університет біоресурсів і природокористування України

В.А. Коренда, І.Ю. Вишняков, О.С. Протасов, Н.В. Бірківська

Український державний науково-дослідний інститут «Ресурс»

\title{
ВИКОРИСТАННЯ ТЕПЛОВИХ НАСОСІВ ДЛЯ ОПАЛЕННЯ БУДІВЕЛЬ НА ПІДПРИЕМСТВАХ
}

Стаття присвячена висвітленню сутності та змісту такої проблеми, як використання установок, що праџюють на альтернативних джерелах енергії для опалення, вентиляції та гарячого водопостачання будівель, а саме теплових насосів. Теплові насоси використовують для своєї роботи низькопотенційне тепло, яке береться з повітря, водойм та надр землі. Підприємства та організаиіі мають різноманітні джерела низькопотенційноі теплової енергії: пожежні водойми, вільні земельні ділянки на територіях.

ТЕПЛОВИЙ НАСОС, ТЕПЛОВА ЕНЕРГІЯ, МОНТАЖ, ТЕПЛОПОСТАЧАННЯ

Постановка проблеми. Тепловий насос - пристрій для переносу теплової енергії від джерела низькопотенційної теплової енергії (з низькою температурою) до споживача (теплоносія) 3 більш високою температурою. Термодинамічний цикл теплового насосу аналогічний холодильній машині. Однак, у холодильній машині основною метою $є$ виробництво холоду шляхом відбору теплоти з будь-якого обсягу випарником, а конденсатор здійснює скидання теплоти в навколишне середовище. В тепловому насосі картина зворотна. Конденсатор $є$ теплообмінним апаратом, що виділяе теплоту для споживача, а випарник - теплообмінним апаратом, що утилізує низько потенційну теплоту: вторинні енергетичні ресурси і (або) нетрадиційні поновлювані джерела енергії.

Залежно від принципу роботи теплові насоси поділяються на компресійні і абсорбційні. Компресійні теплові насоси завжди наводяться в дію за допомогою механічної енергії (електроенергії), в той час як абсорбційні теплові насоси можуть також використовувати тепло в якості джерела енергії (за допомогою електроенергії або палива). Найбільше розповсюдження отримали 
компресійні теплові насоси. Принципова схема компресійного теплового насоса зображена на рис.1.

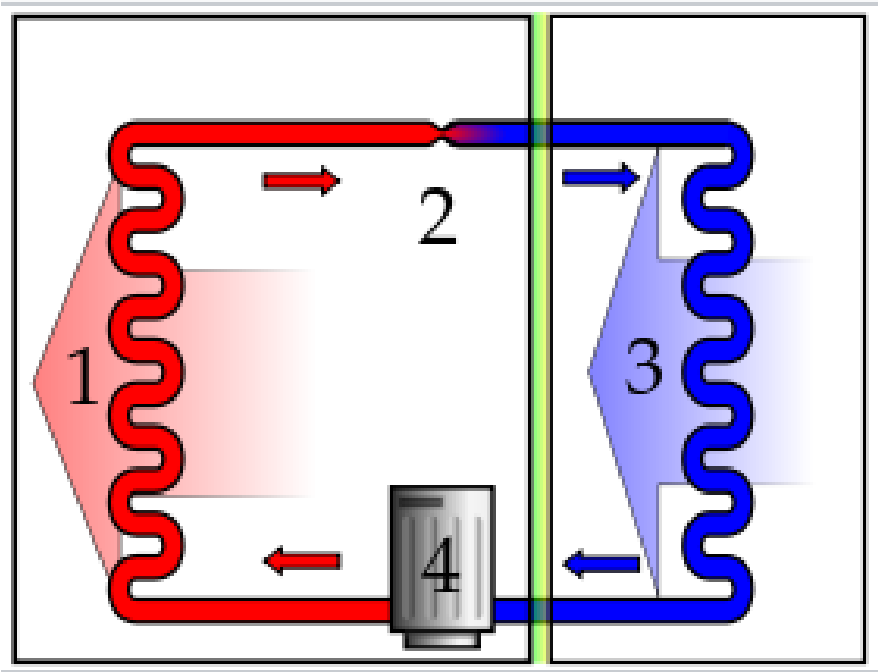

Рис. 1 - Принципова схема: 1 - конденсатор; 2 - дросель; 3 - випарник; 4 -компресор.

В процесі роботи компресор споживає електроенергію. Співвідношення теплової енергії, що виробляється і споживаної електричної називається коефіцієнтом трансформації (або коефіцієнтом продуктивності (англ. СОР - скор. від coefficient of performance) і служить показником ефективності теплового насоса.

Для обчислення СОР використовується наступна формула:

$$
C O P=\frac{Q}{E},
$$

де Q - теплова енергія передана споживачеві, Вт; Е - споживання електричної енергії, Вт.

Аналіз останніх досліджень і публікацій. Залежно від джерела відбору низькопотенційного тепла теплові насоси розділяються на:

1) геотермальні (використовують тепло землі, наземних або підземних грунтових вод):

- горизонтальні (грунт), 
- вертикальні (грунт, гірська порода),

- водні (водойми, грунтові води);

2) повітряні;

3) теплові насоси, які використовують вторинне тепло [5].

За останні роки в різних засобах масової інформації, включаючи Інтернет видання, з'явилися численні публікації, що стосуються використання технології теплових насосів в системах опалення і гарячого водопостачання об'єктів різної сфери - від окремих будинків до житлових мікрорайонів. Виникли десятки компаній, що пропонують теплові насоси різних фірм для згаданих цілей, був прийнятий ряд урядових рішень щодо використання теплових насосів в комунальній сфері[1, 2, 3]. Однак, на сьогоднішній день в Україні не реалізовано жодного, скількинебудь значимого проекту, пов'язаного з використанням теплових насосних технологій. Автори мають багаторічний досвід спільного науково-технологічного співпраці 3 провідними технічними університетами та промисловими компаніями Західної Європи в області розробок і практичного використання теплових насосних технологій.

Сьогодні світ весь час прагне до вдосконалення. В області енергетики це виражається в розвитку енергоефективних технологій. Ще 15-20 років тому більшість новозбудованих будівель розраховувалися за середніми тепловтратами до 100 Вт/м². Зараз практикуючому інженеру-теплотехніку важко уявити собі приміщення з втратою тепла вище, ніж 75 Вт/м², а бувають випадки, коли до уваги береться цифра в 25 т/м².

Внаслідок зниження питомих тепловтрат будівлі актуальною стала тематика низькопотенційних систем опалення.

Актуалізація сталася через те, що знизилися розрахункові температурні режими систем, а це спричинило за собою зменшення габаритних розмірів опалювальних приладів (у більшості випадків радіаторів). Крім того, люди більше почали цінувати незалежність і власний комфорт, чого практично неможливо досягти при використанні будь-якого з традиційних котлів [4, 6].

В 2005 році Королівський Технологічний Інститут Стокгольму та Інститут гідромеханіки Національної Академії наук і СП «Укрінтерм» об'єднали свої зусилля у вивченні досвіду Швеції по використання теплових насосів та його адаптації до українських умов [7, 8, 9]. Зокрема, в 2006 році на черговий виставці «Акватерм» був вперше в Україні показаний діючий тепловий насос шведського виробництва, згодом встановлений в одному з корпусів Київського політехнічного інституту. Було проведено ряд семінарів, 
конференцій та нарад 3 представниками різних органів влади i підприємств, що займаються проблемами теплопостачання, а також представниками проектних організацій. У квітні 2007 року силами представників Королівського Технологічного Інституту (проф. Рональд Венерштен і проф. Берн Пальм) були проведені перші курси по тепловим насосам для студентів теплотехнічного факультету Київського політехнічного інституту.

Основною перевагою теплових насосів $\epsilon$ можливість перемикання з режиму опалення взимку на режим кондиціонування влітку: просто замість радіаторів до зовнішнього колектору підключаються фенкойли або системи «холодний стеля».

Тепловий насос надійний, його роботою керує автоматика. В процесі експлуатації система не потребує спеціального обслуговування, можливі маніпуляції не вимагають особливих навичок і описані в інструкції.

Тепловий насос компактний (його модуль за розмірами не перевищує звичайний холодильник) і практично безшумний.

До недоліків геотермальних теплових насосів, які використовуються для опалення, слід віднести велику вартість встановленого обладнання (300-1200 \$ за 1 кВт встановленої потужності), необхідність складного і дорогого монтажу зовнішніх підземних або підводних теплообмінних контурів. Період окупності теплових насосів становить 4-9 років, при терміні служби 15-20 років до капітального ремонту. Існує і альтернативний погляд на економічну доцільність установки теплових насосів. Так, якщо установка теплового насоса проводиться на кошти, взяті в кредит, економія від використання теплового насосу може бути менше, ніж вартість використання кредиту. Тому масове використання теплових насосів в приватному секторі можна очікувати, якщо вартість теплонасосного обладнання буде порівнянна 3 витратами на установку газового опалення та підключення до газової мережі.

Основним недоліком теплового насоса $\epsilon$ зворотна залежність його ефективності від різниці температур між джерелом теплоти i споживачем. Це накладає певні обмеження на використання систем типу «повітря - вода». Реальні значення ефективності сучасних теплових насосів становлять близько СОР = 2.0 при температурі джерела $-20{ }^{\circ} \mathrm{C}$, i порядку $\mathrm{COP}=4.0$ при температурі джерела $+7{ }^{\circ} \mathrm{C}$. Це призводить до того, що для забезпечення заданого температурного режиму споживача при низьких температурах повітря необхідно використовувати обладнання зі значною надлишковою потужністю, що пов'язане 3 нераціональним використанням капіталовкладень (втім, це 
стосується і будь-яких інших джерел теплової енергії). Всі, навіть найефективніші теплові насоси $\epsilon$ нагрівають воду в системі опалення не більше $+50{ }^{\circ} \mathrm{C} \div+60{ }^{\circ} \mathrm{C}$, причому, чим вище температура води, що нагрівається, тим менше ефективність i надійність теплового насоса. Якщо тепла із зовнішнього контуру все ж недостатньо для опалення в сильні морози, практикується експлуатація насоса в парі з додатковим генератором тепла (в таких випадках говорять про використання бівалентної схеми опалення). Коли вулична температура опускається нижче розрахункового рівня (температури бівалентності), в роботу включається другий генератор тепла - найчастіше невеликий електронагрівач, рідше газовий або твердопаливний котли.

Мета дослідження - визначення доцільності встановлення теплових насосів на підприємствах і організаціях (на прикладі підприємств системи Держрезерву України).

Результати дослідження. Можливості впровадження теплових насосів на підприємствах та організаціях системи Держрезерву наведені нижче в таблиці 1. Розглянемо встановлення водного теплового насосу на прикладі ДО «Комбінат», «Естафета» в м. Славута. На підприємстві знаходяться дві опалювані будівлі адміністративно-побутового (опалюваний об'єм 4532 м3) та господарсько-технічного корпусів (опалюваний об'єм 8263 м3), крім цього в адміністративно-побутовому корпусі також присутня система гарячого водопостачання душових сіток та умивальників (в розрахунках орієнтуємось на 20 чоловік виробничого персоналу). Необхідна теплова потужність теплового насосу на 1 м3 опалюваного об'єму становить 70 Вт/м3, для гарячого водопостачання при витраті на 1 людину 50 літрів води при температурі $45^{\circ} \mathrm{C}$ - 800 Вт/людину. Теплове навантаження адміністративно-побутового корпусу становитиме 333,25 кВт (3 них на гаряче водопостачання 16 кВт), господарсько-технічного корпусу - 578,27 кВт. Враховуючи середньостатистичний коефіцієнт перетворення $\mathrm{COP}=3$ електрична потужність насосів для адміністративно-побутового корпусу становитиме 111,1 кВт, господарсько-технічного корпусу - 192 кВт.

На території підприємства знаходиться пожежне озеро 3 площею 600 м2 та середньою глибиною 3 м. На 10 кВт теплової потужності насоса потрібно до 300 м.п. колектора. 3 врахуванням конструкції водойми та особливостей прокладки колектора, на підприємстві можна встановити лише тепловий насос потужністю 16 кВт для покриття навантаження системи гарячого водопостачання в адміністративному корпусі. Тому для даного 
підприємства найбільш актуальним буде встановлення грунтових теплових насосів.

Таблиця 1 - Можливості впровадження теплових насосів на підприємствах та організаціях системи Держрезерву

\begin{tabular}{|c|c|c|c|c|c|}
\hline $\begin{array}{l}\text { № } \\
\Pi / \Pi\end{array}$ & $\begin{array}{c}\text { Назва } \\
\text { підприємства }\end{array}$ & $\begin{array}{c}\text { Джерело тепло- } \\
\text { постачання }\end{array}$ & Паливо & $\begin{array}{l}\text { Тип теплових насосів, } \\
\text { які можна встановити }\end{array}$ & $\begin{array}{l}\text { Доці- } \\
\text { льні- } \\
\text { сть } \\
\text { вста- } \\
\text { новле- } \\
\text { ння }\end{array}$ \\
\hline 1 & 2 & 3 & 4 & 5 & 6 \\
\hline \multicolumn{6}{|c|}{ Аграрні активи } \\
\hline 1 & $\begin{array}{c}\text { ДП } \\
\text { «Златодар» }\end{array}$ & $\begin{array}{c}\text { Опалення } \\
\text { будівель - } \\
\text { електрокотли }\end{array}$ & - & $\begin{array}{c}\text { Горизонтальні або } \\
\text { вертикальні грунтові, } \\
\text { повітряні, водяні при } \\
\text { наявності пожежної } \\
\text { водойми }\end{array}$ & Так \\
\hline 2 & $\begin{array}{c}\text { ДП } \\
\text { «Кіровоград- } \\
\text { ський КХП } \\
\text { № 2» }\end{array}$ & $\begin{array}{c}\text { Опалення } \\
\text { будівель - } \\
\text { електрокотли }\end{array}$ & $\begin{array}{l}\text { Кам'яне } \\
\text { вугілля }\end{array}$ & $\begin{array}{c}\text { Горизонтальні або } \\
\text { вертикальні грунтові, } \\
\text { повітряні, водяні при } \\
\text { наявності пожежної } \\
\text { водойми }\end{array}$ & Так \\
\hline 3 & $\begin{array}{c}\text { ДП } \\
\text { «Куліндорів- } \\
\text { ський КХП» }\end{array}$ & $\begin{array}{c}\text { Газова коте- } \\
\text { льня - опалення } \\
\text { будівель }\end{array}$ & $\begin{array}{l}\text { Природ- } \\
\text { ний газ }\end{array}$ & $\begin{array}{c}\text { Вертикальні грунтові, } \\
\text { насоси, що } \\
\text { використовують тепло } \\
\text { компресорного } \\
\text { обладнання, повітряні. }\end{array}$ & Так \\
\hline 4 & $\begin{array}{c}\text { ДП } \\
\text { «Охтирський } \\
\text { КХП» }\end{array}$ & $\mid \begin{array}{c}\text { Газова котельня } \\
\text { - опалення } \\
\text { будівель }\end{array}$ & $\begin{array}{l}\text { Природ- } \\
\text { ний газ }\end{array}$ & $\begin{array}{c}\text { Горизонтальні або } \\
\text { вертикальні грунтові, } \\
\text { повітряні, водяні при } \\
\text { наявності пожежної } \\
\text { водойми }\end{array}$ & Так \\
\hline
\end{tabular}


Продовження табл.1

\begin{tabular}{|c|c|c|c|c|c|}
\hline 1 & 2 & 3 & 4 & 5 & 6 \\
\hline 5 & $\begin{array}{c}\text { Філія ДП } \\
\text { «Охтирський } \\
\text { КХП» } \\
\text { «Хлібна база } \\
\text { 82» }\end{array}$ & $\begin{array}{c}\text { Газова міні- } \\
\text { котельня - } \\
\text { опалення } \\
\text { будівель }\end{array}$ & $\begin{array}{c}\text { Природ- } \\
\text { ний газ }\end{array}$ & $\begin{array}{c}\text { Горизонтальні або } \\
\text { вертикальні грунтові, } \\
\text { повітряні, водяні при } \\
\text { наявності пожежної } \\
\text { водойми }\end{array}$ & Так \\
\hline 6 & $\begin{array}{c}\text { ДП } \\
\text { «Стрийський } \\
\text { КХП № 1» }\end{array}$ & $\begin{array}{c}\text { Газова коте- } \\
\text { льня - опалення } \\
\text { будівель }\end{array}$ & $\begin{array}{l}\text { Природ- } \\
\text { ний газ }\end{array}$ & $\begin{array}{c}\text { Горизонтальні або } \\
\text { вертикальні грунтові, } \\
\text { повітряні, водяні при } \\
\text { наявності пожежної } \\
\text { водойми }\end{array}$ & Так \\
\hline 7 & $\begin{array}{c}\text { ДП } \\
\text { «Чортківський } \\
\text { КХП» }\end{array}$ & \begin{tabular}{|c|} 
Газова та \\
твердопаливна \\
міні-котельні - \\
опалення \\
будівель \\
\end{tabular} & $\begin{array}{c}\text { Природ- } \\
\text { ний газ, } \\
\text { дрова }\end{array}$ & $\begin{array}{c}\text { Горизонтальні або } \\
\text { вертикальні грунтові, } \\
\text { повітряні, водяні при } \\
\text { наявності пожежної } \\
\text { водойми } \\
\end{array}$ & Так \\
\hline 8 & $\begin{array}{c}\text { ДП «Хлібна } \\
\text { база № 73» }\end{array}$ & $\begin{array}{c}\text { Твердопаливна } \\
\text { котельня - } \\
\text { опалення } \\
\text { будівель } \\
\end{array}$ & $\begin{array}{l}\text { Кам'яне } \\
\text { вугілля, } \\
\text { дрова }\end{array}$ & $\begin{array}{c}\text { Горизонтальні або } \\
\text { вертикальні грунтові, } \\
\text { водяні при наявності } \\
\text { пожежної водойми }\end{array}$ & Так \\
\hline 9 & $\begin{array}{l}\text { ДП «Хлібна } \\
\text { база № 76» }\end{array}$ & $\begin{array}{c}\text { Твердопаливна } \\
\text { котельня - } \\
\text { опалення } \\
\text { будівель }\end{array}$ & $\begin{array}{c}\text { Кам'яне } \\
\text { вугілля, } \\
\text { дрова }\end{array}$ & $\begin{array}{c}\text { Горизонтальні або } \\
\text { вертикальні грунтові, } \\
\text { водяні при наявності } \\
\text { пожежної водойми }\end{array}$ & Так \\
\hline 10 & $\begin{array}{c}\text { ДП «Хлібна } \\
\text { база № 77» }\end{array}$ & $\begin{array}{c}\text { Твердопаливна } \\
\text { котельня - } \\
\text { опалення } \\
\text { будівель } \\
\end{array}$ & $\begin{array}{c}\text { Кам'яне } \\
\text { вугілля, } \\
\text { дрова }\end{array}$ & $\begin{array}{c}\text { Горизонтальні або } \\
\text { вертикальні грунтові } \\
\text { при наявності } \\
\text { пожежної водойми }\end{array}$ & Так \\
\hline 11 & $\begin{array}{l}\text { ДП «Хлібна } \\
\text { база № 85» }\end{array}$ & $\begin{array}{c}\text { Опалення } \\
\text { будівель - } \\
\text { електрокотли } \\
\end{array}$ & - & $\begin{array}{c}\text { Горизонтальні або } \\
\text { вертикальні грунтові }\end{array}$ & Так \\
\hline
\end{tabular}


Продовження табл.1

\begin{tabular}{|c|c|c|c|c|c|}
\hline \multicolumn{6}{|c|}{ Склади та холодильники } \\
\hline 1 & 2 & 3 & 4 & 5 & 6 \\
\hline 12 & $\begin{array}{c}\text { ДО } \\
\text { "Комбінат } \\
\text { "Прогрес" }\end{array}$ & $\begin{array}{c}\text { Газова } \\
\text { котельня - } \\
\text { опалення } \\
\text { будівель } \\
\end{array}$ & $\begin{array}{l}\text { Природ- } \\
\text { ний газ }\end{array}$ & Вертикальні грунтові & Так \\
\hline 13 & $\begin{array}{c}\text { ДО } \\
\text { "Комбінат } \\
\text { "Дніпро" }\end{array}$ & $\begin{array}{c}\text { Газова } \\
\text { котельня - } \\
\text { опалення } \\
\text { будівель } \\
\end{array}$ & $\begin{array}{l}\text { Природ- } \\
\text { ний газ }\end{array}$ & $\begin{array}{l}\text { Горизонтальні або } \\
\text { вертикальні грунтові }\end{array}$ & Так \\
\hline 14 & $\begin{array}{c}\text { ДО } \\
\text { "Комбінат } \\
\text { "Салют" }\end{array}$ & $\begin{array}{c}\text { Опалення } \\
\text { будівель - } \\
\text { електрокотли }\end{array}$ & - & Вертикальні грунтові & Так \\
\hline 15 & $\begin{array}{c}\text { ДО } \\
\text { "Комбінат } \\
\text { "Світанок" }\end{array}$ & $\begin{array}{c}\text { Опалення } \\
\text { будівель - } \\
\text { електрокотли }\end{array}$ & - & Вертикальні грунтові & Так \\
\hline 16 & $\begin{array}{c}\text { ДО } \\
\text { "Комбінат } \\
\text { "Трикутник" }\end{array}$ & $\begin{array}{c}\text { Котельні } \\
\text { газова та } \\
\text { твердопаливна } \\
\text { опалення } \\
\text { будівель }\end{array}$ & $\begin{array}{l}\text { Природ- } \\
\text { ний газ; } \\
\text { вугілля }\end{array}$ & Вертикальні грунтові & Так \\
\hline 17 & $\begin{array}{l}\text { ДО "Комбінат } \\
\text { “Троянда" }\end{array}$ & $\begin{array}{c}\text { Котельня на } \\
\text { вугільних } \\
\text { брикетах - } \\
\text { опалення } \\
\text { будівель } \\
\end{array}$ & $\begin{array}{l}\text { Вугільні } \\
\text { брикети }\end{array}$ & Вертикальні грунтові & Так \\
\hline 18 & $\begin{array}{c}\text { ДО “Укрпрод- } \\
\text { контракт” }\end{array}$ & $\begin{array}{c}\text { Твердопаливна } \\
\text { котельня - } \\
\text { опалення } \\
\text { будівель }\end{array}$ & $\begin{array}{c}\text { Кам'яне } \\
\text { вугілля, } \\
\text { дрова }\end{array}$ & Вертикальні грунтові & Так \\
\hline
\end{tabular}


Продовження табл.1

\begin{tabular}{|c|c|c|c|c|c|}
\hline \multicolumn{6}{|c|}{ Нафтобази } \\
\hline 19 & $\begin{array}{c}\text { ДО } \\
\text { "Комбінат } \\
\text { "Айстра" }\end{array}$ & $\begin{array}{c}\text { Твердопаливна } \\
\text { котельня - } \\
\text { опалення } \\
\text { будівель }\end{array}$ & Дрова & \begin{tabular}{|c|} 
Вертикальні та \\
горизонтальні грунтові \\
при наявності \\
пожежної водойми
\end{tabular} & $\mathrm{Hi}$ \\
\hline 20 & $\begin{array}{c}\text { ДО } \\
\text { "Комбінат } \\
\text { "Рекорд" }\end{array}$ & $\begin{array}{c}\text { Твердопаливна } \\
\text { котельня - } \\
\text { опалення } \\
\text { будівель } \\
\end{array}$ & Дрова & \begin{tabular}{|c|} 
Вертикальні та \\
горизонтальні грунтові \\
при наявності \\
пожежної водойми \\
\end{tabular} & $\mathrm{Hi}$ \\
\hline 21 & $\begin{array}{c}\text { ДО } \\
\text { "Комбінат } \\
\text { "Естафета" }\end{array}$ & Централізоване & - & \begin{tabular}{|c|} 
Вертикальні та \\
горизонтальні грунтові \\
при наявності \\
пожежної водойми \\
\end{tabular} & $\mathrm{Hi}$ \\
\hline 22 & $\begin{array}{c}\text { ДО } \\
\text { "Комбінат } \\
\text { "Зірка" } \\
\text { (ділянка } \\
\text { Запоріжжя) }\end{array}$ & $\begin{array}{c}\text { Твердопаливна } \\
\text { котельня - } \\
\text { опалення } \\
\text { будівель }\end{array}$ & Дрова & Водні & $\mathrm{Hi}$ \\
\hline 23 & $\begin{array}{c}\text { ДО } \\
\text { "Комбінат } \\
\text { "Зірка" } \\
\text { (ділянка } \\
\text { Бердянськ) } \\
\end{array}$ & $\begin{array}{c}\text { Твердопаливна } \\
\text { котельня - } \\
\text { опалення } \\
\text { будівель }\end{array}$ & Дрова & Водні & $\mathrm{Hi}$ \\
\hline 24 & $\begin{array}{c}\text { ДО } \\
\text { "Комбінат } \\
\text { "Планета" }\end{array}$ & $\begin{array}{c}\text { Котельні } \\
\text { газова та } \\
\text { твердопаливна - } \\
\text { опалення } \\
\text { будівель }\end{array}$ & $\begin{array}{c}\text { Природ- } \\
\text { ний газ, } \\
\text { дрова }\end{array}$ & $\begin{array}{c}\text { Вертикальні та } \\
\text { горизонтальні грунтові } \\
\text { при наявності } \\
\text { пожежної водойми }\end{array}$ & $\mathrm{Hi}$ \\
\hline
\end{tabular}

Висновки. 1. Використання теплових насосів передбачає лише оплату за електроенергію на роботу та технічне обслуговування установки, сума у порівнянні 3 витратами на центральне опалення або роботу газових або електричних котлів аналогічної потужності в декілька разів менша. 2. Впровадження теплових насосів $\epsilon$ перспективним напрямком використання альтернативних джерел енергії для забезпечення потреб систем опалення, вентиляції та гарячого водопостачання будівель, але даний процес суттєво залежить від місцезнаходження об'єкта та наявності доступу до певного оптимального для нього джерела низько потенціальної теплової енергії. 3. Термін окупності від впровадження теплового насоса, не зважаючи на високу собівартість установки (300-1200\$ за 1 кВт потужності) та складний 
монтаж зовнішніх підземних або підводних теплообмінних контурів, становить на даний момент 4-9 років. Але в останній час спостерігається тенденція поступового зниження собівартості обладнання та його монтажу

\section{Література}

1. Закон України «Про альтернативні джерела енергії».

2. Закон України №1959-VIII від 21.03.2017 "Про внесення змін до Закону України "Про теплопостачання" щодо стимулювання виробництва теплової енергії з альтернативних джерел енергії".

3. Теплонасосні установки в харчовій та іншій галузях: публікація в рамках проекту UNIDO «Підвищення нергоефективності та стимулювання використання відновлюваної енергії в агро-харчових та інших малих та середніх підприємствах (МСП) України» / В.Ф. Мокляк, О.М. Рябчук. К.: ЮНІДО, 2015.

4. Енергетична ефективність теплонасосних схем теплопостачання: моногр. / М.К. Безродний, Н.О. Притула. - К.: НТУУ «КПІ», 2012. - 208 c.

5. Пісарев В.С. Теплові насоси та холодильні установки. Навчальний посібник. - К.: КНУБА, 2002. - 124c.

6. Снєжкін Ю.Ф., Чалаєв Д.М., Шаврін В.С., Дабіжа Н.О. Теплові насоси в системах теплохолодопостачання [монографія]// під під ред. акад. НАН України А.А. Долінського; НАН України, Інт техн. теплофізики. - К.: [б. в.], 2008. - 104c.

7. Ткаченко С.Й., Остапенко О.П. Парокомпресійні теплонасосні установки в системах теплопостачання. - Вінниця: ВНТУ, 2009. $177 \mathrm{c}$.

8. Руководство по проектированию и монтажу теплових насосов Dimplex [Електронний pecypc]// Режим доступу http://geowatt.kz/downloads/HP_planning_and_installation_Rus.pdf

9. Васьков Е.Т. Термодинамические основы тепловых насосов: учебное пособие/ СПб гос.архит. - строит. ун-т. - СПб, 2007. $127 \mathrm{c}$. 